American Journal of Environmental Sciences 6 (6): 484-488, 2010

ISSN 1553-345X

(C) 2010 Science Publications

\title{
Weight of Evidence Allocates Mineral Depositional Zones
}

\author{
${ }^{1}$ Abdullah A. Bokhari, ${ }^{1}$ Guang Dao HU and ${ }^{2}$ Rani Fouad \\ ${ }^{1}$ Institute of Mathematic Geology and Remote Sensing Geology, \\ Faculty of Earth Resources, Geodetection and Information Technology Department, \\ China University of Geosciences, Wuhan, China 430074 \\ ${ }^{2}$ Faculty of Engineering, Civil Department, Al-Azhar University, Cairo, Egypt 11341
}

\begin{abstract}
Problem statement: Yunnan province in general and Pulang area in particular is geological rich area which prevents field study in multi locations due to high risk outcrop. Approach: New technology such as Geographic Information System (GIS) and an ArcView extension module Arcweight of evidence (WofE) became very handy to provide safety for researchers and allow organization to control their budget. Results: In order to guide mineral exploration, to achieve the purpose of rapid evaluation of mineral resources a serial of modeled prediction methods were established. Weight of evidence model is to predict the existent thing by combining the known evidence of the study area, the importance of evidence is determined based on statistical method. Contrary to the fuzzy logic method, it avoids the subjective selection of evidence and the subjective evaluation of evidence. The weight of evidence can determine the weight in the same standard conditions (using known mine sites as guidance data), so that the variables can be compared in the united scale, a higher reliability. Conclusion/Recommendations: Comparing predicted and known distribution patterns of porphyry, most mine sites are located in the areas with high posterior probability, forecast area accounts for $11.5 \%$ of the entire study area. Predicted results show clearly that the boundary of potential areas and the non-potential areas is clear. Therefore, fuzzy logic and other methods should be applied to predict the results for further comparison. More accurate prediction would draw a big smile on faces of share holders.
\end{abstract}

Key words: Arc-WofE, depositional zones, evidence allocates, Geographic Information System (GIS), pulang area, fuzzy logic method

\section{INTRODUCTION}

Pulang area is located in the northwestern part of Yunnan province, southwestern part of China (Fig. 1). At present with the gradual increase in difficulty exploration, new technologies and new methods should be introduced to achieve a breakthrough in mineral resources prediction (Jiang and Kader, 2003). With the rapid development in Geographic Information System (GIS) and the gradual improvement in basic geology, geophysics, geochemistry, remote sensing database of China, mineral exploration has become increasingly expedient (Yandeng, 1999). The study of new methods and new theories should be required to establish a serial of modeled prediction methods in order to guide mineral exploration, to achieve the purpose of rapid evaluation of mineral resources (Yan Ming et al., 2003; Zhang, 2002).

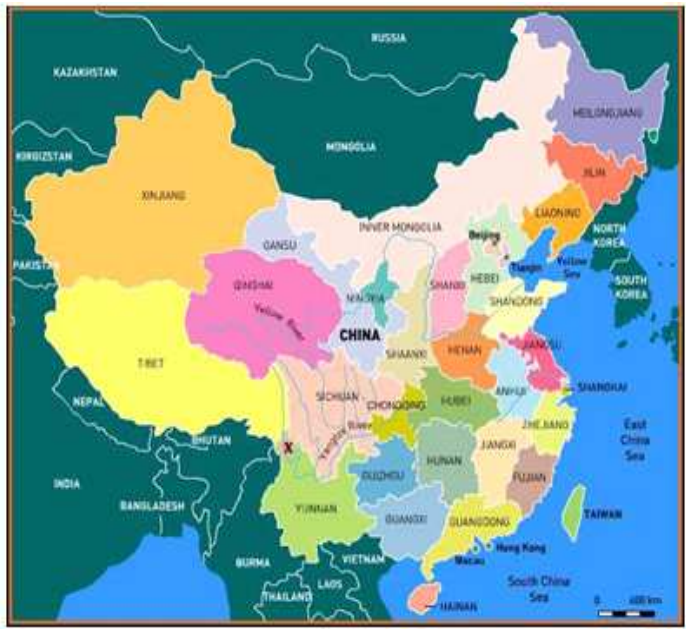

Fig. 1: Location map of study area. Northwest of Yunnan province $(\mathrm{X})$, southwest of China

Corresponding Author: Abdullah A. Bokhari, Institute of Mathematic Geology and Remote Sensing Geology, Faculty of Earth Resources; China University of Geosciences Wuhan, China 430074 Mobile: 008613554238582 Fax: 00862767848637. 
Porphyry copper in Yunnan Pulang area, as the main object of research, was studied with digital technologies, including GIS-based prediction of mineral resource potential, construction of databases in this region, integration of factors of geological background and ore-controlling, establishment of mathematical deposit exploration mode, rapid and accurate position of exploration and evaluation area and identification of porphyry copper resource potential among studied zones.

Assumption and definition: The weight of evidence model was originally based on a series of symptoms of the existence or non-existent, to predict the possibility of a patient taking certain disease (Qiuming, 2002). Recently, this method is still used in medical fields. The model had applied to evaluation of mineral resources since in the late eighties (Bonham-Carter et al., 1989). For example, the method is applied to Nova Scotia gold deposits (Xiaojun, 2000), this model also applied to evaluation of the distribution of other resources, such as the Copper (Bonham-Carter, 2006). Recently, weight of evidence model is developed as an ArcView extension module Arc- weight of evidence (WofE). Arc-WofE has been widely used in mineral exploration and environmental assessment (Haifeng et al., 2003).

\section{MATERIALS AND METHODS}

The weight of evidence model can provide the measure standard (weight) to determine the relation between two-value layers and point objects and predict the spatial distribution of point objects. When the model is applied to mineral prediction, point objects are deposits (points); the evidence layers are the thematic maps of geological, geochemical and geophysical objects favorable to mineralization prediction. Evidence layer is generally a discontinuous area (usually binary variable) (Liu and Road, 2003). 1 is the representative of existent evidence, 0 is the representative of non-existent evidence. This allows relationships between the evidence layers and deposits (points) spatial more explicit.

\section{The crucial steps are:}

Weight calculation: Weight calculation is the calculation of each unit weight of the grid, first of all, to grid the entire study area. Conditional probability are used to calculate the weight of the evidence layers and deposits (points) (equation 1), $\mathrm{W}^{+}$shows that evidence layers exist, $\mathrm{W}^{-}$shows that the evidence layer does not exist. The size of the weight is relative, dimensionless (Feng et al., 2003).
$\mathrm{W}^{+}=\ln \frac{\mathrm{P}(\mathrm{B} / \mathrm{D})}{\mathrm{P}(\mathrm{B} / \overline{\mathrm{D}})}-\mathrm{W}^{-}=\ln \frac{\mathrm{P}(\overline{\mathrm{B}} / \mathrm{D})}{\mathrm{P}(\overline{\mathrm{B}} / \overline{\mathrm{D}})}$

Positive correlation of evidence layers and mine sites is expressed by $\mathrm{W}^{+}>0, \mathrm{~W}^{-}<0$. Negative correlation is $\mathrm{W}^{+}<0, \mathrm{~W}^{-}>0$. When it is not relevant, the weight is 0 . When missing data, we also believe that the weight is 0 . Relative coefficient of $\mathrm{C}=\mathrm{W}^{+}-\mathrm{W}^{-}$, is used to measure the correlation between layers of evidence and minerals.

Evidence integration: Binary-value thematic layers (evidence layer) applied Bayesian linear logarithm to integrate and calculate the total weight when such evidence layers exist at the same time, finally to produce potential maps of known deposits and potential deposits (Hansen, 2000).

In practical application, the weight of evidence using probability logarithm to express Bayesian rules, in this way, the model becomes linear, easier to add:

$$
\begin{aligned}
& \ln \mathrm{O}\left(\mathrm{D} / \mathrm{B}_{1}{ }^{\mathrm{K}(1)} \mathrm{B}_{2}{ }^{\mathrm{K}(2)} \cdots \mathrm{B}_{\mathrm{n}}{ }^{\mathrm{k}(\mathrm{n})}\right) \\
& =\mathrm{W}_{0}+\mathrm{W}^{+}{ }_{1}\left(\mathrm{orW}^{-}{ }_{1}\right)+\mathrm{W}^{+}{ }_{2}\left(\mathrm{orW}_{2}{ }_{2}\right)+\cdots+\mathrm{W}^{+}{ }_{\mathrm{n}}\left(\mathrm{orW}^{-}{ }_{\mathrm{n}}\right) \\
& =\sum_{\mathrm{i}=0}^{\mathrm{n}} \mathrm{W}_{\mathrm{i}}{ }^{\mathrm{k}}
\end{aligned}
$$

Where

$\mathrm{O}$

$\mathrm{D}=$ The number of ore-element grid

$\mathrm{B}_{\mathrm{j}} \quad=$ On behalf of the jth-layer

$\mathrm{K}^{(\mathrm{j})} \quad=+$ when the $\mathrm{jth}$ evidence layer exists, otherwise

$\mathrm{K}(\mathrm{j})$ is,$- \mathrm{W}_{\mathrm{j}}=$ The weights of the $\mathrm{jth}$ predictive variable

In general, the weight of evidence model mainly involves three basic concepts, weight $\left(\mathrm{W}^{+}\right)$, preinspection probability and posterior probability, the weight of evidence stands for the relevance of orecontrolling evidence layer to ore-mining point; the preinspection probability is the density (Bonham-Carter et al., 1988). Posterior probability is the ultimate probability. In the grid area, the pre-inspection probability of cell grid varies as the new evidence of the cell layer and eventually to get the posterior probability of the cell. A posterior probability can be larger or smaller than the pre-inspection probability, this depends primarily on the evidence of superimposed layers and their weights.

\section{Application}

Binary variables: Weight of evidence, first of all, variables binary operation must be carried out, the choice of threshold is based on calculation of individual weights of evidence, for example, as for the geochemical anomaly; first of all, calculate the weight of different grades: 
Am. J. Environ. Sci., 6 (6): 484-488, 2010

Table 1 Evidence layers for porphyry copper mineral potential models

\begin{tabular}{|c|c|c|c|c|c|c|c|c|c|}
\hline \multirow[b]{2}{*}{ Binary Map } & \multicolumn{9}{|c|}{ Evidence layers for porphyry copper mineral potenital models } \\
\hline & Area $(\mathrm{Km} 2)$ & Desposit & $\mathrm{W}+$ & $\mathrm{S}\left(\mathrm{W}^{+}\right)$ & W- & $\mathrm{S}\left(\mathrm{W}^{-}\right)$ & $\mathrm{C}$ & $\mathrm{S}(\mathrm{c})$ & Stud(c) \\
\hline Porphyry & 954.3301 & 15 & 1.145 & 0.262 & -1.269 & 0.501 & 2.414 & 0.565 & 4.270 \\
\hline Aeromagnetics & 1040.954 & 11 & 0.737 & 0.305 & -0.541 & 0.355 & 1.278 & 0.468 & 2.733 \\
\hline Garvity & 1960.659 & 17 & 0.536 & 0.245 & -1.509 & 0.708 & 2.045 & 0.749 & 2.730 \\
\hline NW fault & 2424.554 & 16 & 0.260 & 0.252 & -0.798 & 0.579 & 1.058 & 0.631 & 1.676 \\
\hline Non-Nwfault & 1370.885 & 9 & 0.253 & 0.336 & -0.183 & 0.318 & 0.436 & 0.462 & 0.944 \\
\hline Center systmetry & 2234.099 & 15 & 0.276 & 0.260 & -0.644 & 0.501 & 0.920 & 0.565 & 1.628 \\
\hline $\mathrm{Cu}$ & 1176.145 & 14 & 0.859 & 0.271 & -0.961 & 0.448 & 1.820 & 0.523 & 3.477 \\
\hline Mo & 674.3559 & 13 & 1.356 & 0.283 & -0.959 & 0.409 & 2.315 & 0.497 & 4.655 \\
\hline F2 factor & 1125.168 & 11 & 0.658 & 0.305 & -0.508 & 0.355 & 1.166 & 0.467 & 2.495 \\
\hline $\mathrm{Ba} / \mathrm{Na}$ & 1285.203 & 12 & 0.611 & 0.291 & -0.579 & 0.379 & 1.190 & 0.478 & 2.488 \\
\hline
\end{tabular}

Table 2 Conditional Independence test of evidence layers

\begin{tabular}{|c|c|c|c|c|c|c|c|c|c|}
\hline \multirow[b]{2}{*}{ Weight leayer } & \multicolumn{9}{|c|}{ Conditional independence test of evidence layers } \\
\hline & Garvity & Aeromagnetic & Non-NF fault & NW fault & Center sysmetry & $\mathrm{Ba} / \mathrm{Na}$ & $\mathrm{Cu}$ & Mo & F2 factor \\
\hline Porphyry & 0.02 & 0.86 & 0.47 & 0.32 & 0.22 & 5.59 & 0.50 & 0.85 & 1.82 \\
\hline Garvity & & 0.27 & 0.01 & 0.14 & 0.02 & 0.17 & 0.00 & 0.04 & 0.27 \\
\hline Aeromagnetic & & & 0.07 & 0.95 & 1.82 & 0.00 & 2.87 & 1.05 & 0.67 \\
\hline Non-NF fault & & & & 0.28 & 0.20 & 1.27 & 0.82 & 0.11 & 1.44 \\
\hline NW fault & & & & & 1.80 & 0.27 & 1.03 & 0.56 & 0.09 \\
\hline Center symmetr & & & & & & 0.00 & 0.33 & 0.08 & 0.86 \\
\hline $\mathrm{Ba} / \mathrm{Na}$ & & & & & & & 0.14 & 0.53 & 0.00 \\
\hline $\mathrm{Cu}$ & & & & & & & & 4.64 & 2.17 \\
\hline Mo & & & & & & & & & 0.22 \\
\hline
\end{tabular}

- Porphyry: $\mathrm{A}_{1}=(1$; exists $), \mathrm{A} 2=(0$; does not exist $)$

- Gravity: $\mathrm{A}_{1}=(1$; gradient zone $), \mathrm{A} 2=(0$; nongradient zone)

- Aeromagnetic: $\mathrm{A}_{1}=(1 ; \Delta \mathrm{T} \geq 0.00637, \Delta \mathrm{T} \leq-$ $0.031), \mathrm{A}_{2}=(0 ;-0.031<\Delta \mathrm{T}<0.00637)$

- Non-NW-trending fault $\mathrm{A}_{1}=(1$; buffer zone $\leq$ $1.25 \mathrm{~km}), \mathrm{A}_{2}=(0$; buffer zone is greater than $5 \mathrm{~km})$

- $\quad$ Center symmetry $A_{1}=(1 ; 0.3 \leq$ symmetry $\leq 0.5)$, $\mathrm{A}_{2}=((0 ;$ symmetry $>0.5$, symmetry $<0.3)$

- $\quad \mathrm{NW}$-trending fault $\mathrm{A}_{1}=(1 ;$ buffer $\leq 2 \mathrm{~km}), \mathrm{A}_{2}=(0$; buffer $<1 \mathrm{~km}$ )

- $\quad \mathrm{Cu}$ element $\mathrm{A}_{1}=(1$; content $\geq 95.234), \mathrm{A}_{2}=(0$; content $<$; 95.1)

- $\quad$ Mo element $\mathrm{A}_{1}=(1 ;$ content $\geq 1.59), \mathrm{A}_{2}=(0$; content <1.59)

- $\quad \mathrm{F} 2$ element $\mathrm{A}_{1}=(1 ;$ content of $\geq 0.454), \mathrm{A}_{2}=(0$; content $<0.454)$

- $\quad \mathrm{Ba} / \mathrm{Na} \mathrm{A}_{1}=(1$; ratio of $\geq 0.088), \mathrm{A}_{2}=(0$; ratio $<0.0 .088)$

The standard of binary-valued on the evidence layer, can be customized (Shao-Yang, 2002), can also be calculated by measuring the relativity of the coefficient C. Evidence-layer binary can use models to calculate the weights of evidence that determine the status of evidence existence (Table 1).

Evidence integration: Conditional independence is the right evidence, the premise of an integrated model, the application modules Arc-WofE paired tests on the two layers of the independence of the value of the evidence examined to generate a $x^{2}$ value of the matrix. $x^{2}$ value represents the independence between the predictor variable sizes, the smaller the value, the greater the independence (Yan Ming et al., 2003). Evidence-layer production produced a lot of evidence layers, such as rock diversity of maps, the average fault location map, fracture density maps and so on, but the test for independence, these maps and selected the evidence, or between the layers (Table 1) that there exists significant conditions are not independent, $\mathrm{x}^{2}$ values are greater than 5.4. Finally, therefore, have to be removed. Table 2 is to preserve the independence between the tests of evidence, in line with the conditions of application of weight of evidence.

Table 1 is the ultimate choice of the evidence ore layer, deposit, evidence of property of a column that exists on the unit for a number of ore deposits, applied the formula 2 Table 1 the evidence in the consolidated layer, calculated when the evidence of the presence of the various floors at the same grid cell weight and, ultimately be in the study area of the porphyry copper mineral potential map (posterior probability chart) (Fig. 3).

\section{RESULT AND DISCUSSION}

From a histogram of potential area classes (Fig. 2) as well as the potential map (Fig. 3), in the upper part of 


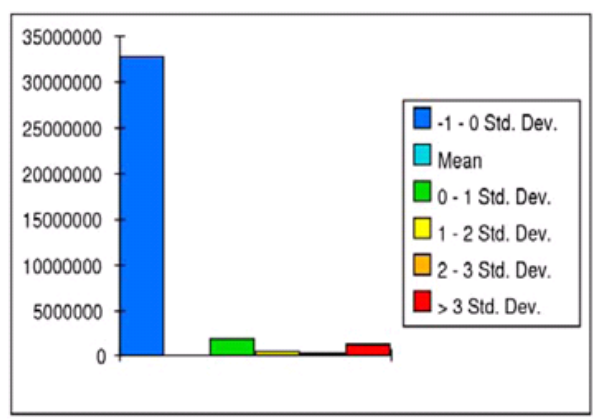

Fig. 2 Histogram of potential area classes

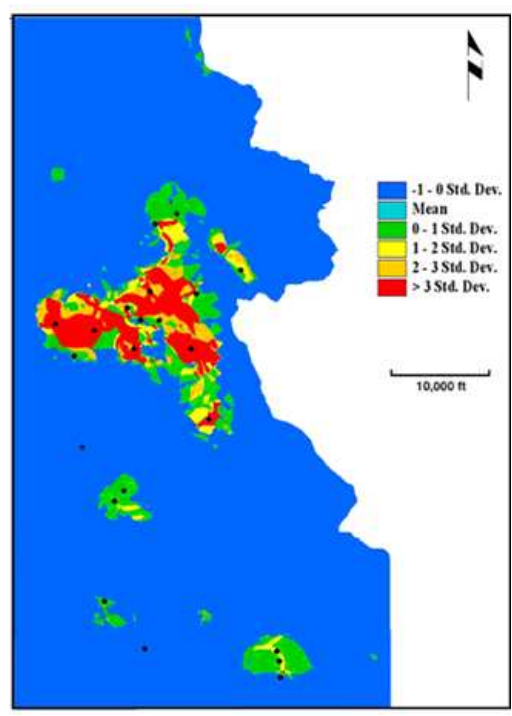

Fig. 3: Mineral potential map for porphyry copper in Pulang area

Qiansui-Disuga ore concentration area, is the best location for porphyry copper deposits exploitation, the upper part of Langdang, also have a higher potential. According to information received from mineral potential map, $90 \%$ of the known ore points are forecasted, while the long-term forecast areas only account for $11.5 \%$ of the forecast areas, this result is marvelous.

\section{CONCLUSION}

The weight of evidence modeling has its merits, but also has its shortcomings. This approach is data-driven, avoiding the subjective assessment of weight, its maps are binary-valued, thus enabling the spatial relationship of evidence and deposits more clear, independence assumption also make it easier for the evidence-layer synthesis; on the other hand, the process of the binary- valued, often results in the loss of ore-controlling information. Therefore, fuzzy logic and other methods should be applied to predict the results for further comparison.

\section{ACKNOWLEDGMENT}

I would like to acknowledge the Ministry of Higher Education, Saudi Arabia; Saudi Arabian Cultural Mission in Beijing, China, for their encouragement and financial support throughout this study, even though the latter still has to be paid back.

My sincere appreciation is extended to the professors at Institute of Mathematic Geology and Remote Sensing Geology; Faculty of Earth Resources at China University of Geosciences, Wuhan, China.

Professor $\mathrm{Hu}$ Guang Dao provided advice and comments essential to the completion of this study. His advice, support and patience are highly appreciated. Thanks are also extended to Dr. Mei H.B., Dr. Xue W.X. and Dr. Rani Fouad, for their advice and input

Finally, thanks Wafai. I know thanks would not express my appreciation to those listed above! Sorry if I neglected to mention anyone!

\section{REFERENCES}

Bonham-Carter, G.F., F.P. Agterberg and D.F. Wright, 1988. Integration of geological datasets for gold exploration in nova scotia. Am. Soc. Photogrammetry Remote Sens., 54: 1585-1592.

Bonham-Carter, G.F., F.P. Agterberg and D.F. Wright, 1989. Weights of evidence modeling: A new approach to mapping mineral potential. In: Statical Applications in the Earth Sciences, Agterberg, F.P., Bonham-Carter, G.F., (Eds.). Geological Survey of Canada, pp: 171-183.

Bonham-Carter,G.F., 2006. Geographic Information System For Geosciences: Modelling With Gis. Pergamon Press,Oxford, Volume 13

Feng, Y., T.F. Zhou and Y.S. Cang, 2003. GIS prediction of mineral resources, the weight of evidence law. Gold Geol. J., 3: 75-77.

Haifeng, H. Y.S. Zhen, D.I.N.G. Zhen-ju, 2003. GISbased weights of evidence method in metallogenic prediction - min county, gansu province-lixian gold as an example to the region. Geological Sci. Technol. Inform. 3: 77-82.

Hansen, D.T., 2000. Describing Gis Applications: Spatial Statistics And Weights of Evidence Extension To Arcview In The Analysis Of The Distribution Of Archaeology Sites In The Landscape.In:Proceedings Of The Archaeology Sites In The Coference,San Diego,United States. Http://Www01.Giscafe.Com/Technical_Papers/Pap ers/Paper054/(Accessed On May.8 2004). 
Jiang, Y.M. and P.A. Kader, 2003. Weight of evidence in the metallogenic prediction. Xinjiang Geol. 4: 491-492.

Liu, X. and H. Road, 2003. Application MORPAS system weights of evidence method for multisource information metallogenic prediction-in the southern section of the Lancang River area as an example. Geol. Explorat. 4: 65-68.

Shao-Yang, H., 2002. Based on arcview 3.2 weight of evidence law in interlayer oxidation zone sandstone-type uranium deposits in the application of quantitative evaluation. Geophys. Geochem. Explorat. J., 6: 443-449.
Xiaojun, Z., 2000. The weight of evidence in northwest Sichuan gold model and its prediction applications. Geolog. J. Univ., 4: 554-560.

Yandeng, X.K., 1999. Metallogenic prediction weights of evidence method and its comparison with the amount of information. Geophys. Geochem. Explorat. Technol., 03: 223-226.

Zhang, Q.C.S., 2002. Fuzzy weight of evidence method implemented in geodas gis for information extraction and intergration for prediction of point events. Ieee, 2933-2935. ISBN: 0-7803-7536-X 